\title{
ERRATUM
}

Wendy A. Howard · Jon M. Bible •

Eva Finlay-Dijsselbloem • Sam Openshaw •

Deborah K. Dunn-Walters

\section{Immunoglobulin light-chain genes in the rhesus macaque I: kappa light-chain germline sequences for subgroups IGKV1, IGKV2 and IGKV3}

Published online: 22 October 2005

(C) Springer-Verlag 2005

Immunogenetics (2005) 57: 210-218

There was a spelling mistake in the title of this article. The 2 was missing from IGKV2. The correct title is printed above.

The online version of the original article can be found at http://dx. doi.org/10.1007/s00251-005-0794-2.

W. A. Howard · J. M. Bible · E. Finlay-Dijsselbloem .

S. Openshaw · D. K. Dunn-Walters $(\Delta)$

Department of Immunobiology, Guy's Kings and St Thomas'

Medical School, King's College London, Guy's Hospital,

London, SE1 9RT, UK

e-mail: Deborah.dunn-walters@kcl.ac.uk

Tel.: +44-20-71883058

Fax: $+44-20-71883385$ 